\title{
prague $^{\mathrm{TM}}$ \\ JULIAN HARRIS
}

Vaclav sat back in a chair and looked out of the living room window of his apartment. He had a glass of whisky and a cigarette burning in an ashtray on the windowsill. A Danish modern jazz band was playing on the stereo (a friend had posted the recording from Denmark and the CD had arrived that day).

He looked across at the builders working on the studio apartment across the street. It was a gorgeous day. The builders were sitting on the bench they had erected from bricks and planks of wood, their shovels downed and the cement-mixer idle. There was a wheelbarrow, several sacks of lime, and a shopping trolley on its side. The workers were drinking beer in the morning sun and had their shirts off. Two of the men showed off white flabby bellies. Butter wouldn't have melted in their mouths. Vaclav watched the lazy d runks listening to music on the radio and drinking in the morning. He wondered for a second whether he envied the men. Impossible. Chalk and cheese.

On such occasions-watching outdoor scenes reflected in a glass of whisky-he felt so rry for the ideals of socialism as he observed the raw material it had had to work with, right there across the street. Vaclav wasn't a socialist but he did like things on paper: drawings, paintings, poems, written music scores and political ideas. And socialism looked good on paper, better sometimes on celluloid. He had studied ideology closely in history and politics lessons at Swiss boarding school, obliged by classmates to adopt a team: fascism, socialism or Spanish anarchism. He had researched and reproduced the artworks of early-twentieth-century Soviet 'social realism'. Compared with the wasted ectomorphs of German expressionism, social realism had re-engaged with the noble human form of classical art. He wasn't certain he agreed with the idea that fascism alone 
was the aestheticisation of politics. More to the point, Vaclav wasn't sure he understood what the comment - that he often heard at gallery parties and had read in art reviewsmeant. That fascism and fascists looked good? Sexy even? Was that the idea? Shiny boots of leather? Socialism had its aesthetic side as well. Castro and Guevara, Camus and Steinbeck, Mayakovsky and Picasso. Vaclav lined up the two teams beside each other: the Fascists and the Socialists. He needed a few more women to make things interesting. Was Simone de Beauvoir actually a socialist? Was Leni Riefenstahl really a fascist? Vaclav wanted to include them both in teams. He needed to look up some African leaders as well. The task was an onerous one. Vaclav's early money was on socialism. Of course, the anarchists were never to be discounted.

Socialism had its fair share of mythical heroes made new and writ large in marble and granite. Vaclav tried to remember from schooldays whether it was the Hellenic students in the Classical Society who had embraced fascism (Hitler, of course, over Mussolini) and the Romanophiles who opted for socialism. The later statues and sculptures called 'social realism' had always seemed anything but realistic. They were vulgar and crude prison guards. The heroic status of labour celebrated by the monumental statues of blacksmiths and the murals of workers assembling farm and aircraft machinery in factories seemed quite unreal. Vaclav would have preferred Greek gods for all the use and truth of the a rtworks. Though, of course, he was biased.

The reality was the workers across the street, loafing in sunshine and drinking. The train station murals and public square monuments should have depicted these workers and, perhaps, socialism might have had a better chance of working. Sure, there was meaningful work to be done, but not that much, and you needn't be completely sober about it. Joyous labour might just have been an intellectual's myth and certainly wasn't to everyone's tastes.

Those who would prefer to be somewhere else-in the woods, camping, skiing, fishing, playing music—needn't have had joyous labour, just painless employment. Should they be able to drink or read or sleep on the job, even better. These were the sculptures that Vaclav—had he not been tucked away in boarding school—would have produced in some forbidden studio underground during the 1970s in Prague, hanging out with the Plastic People of the Universe. That is, had he lived in Czechoslovakia during the seventies and not in Switzerland.

The first series of sculptures_-Vaclav imagined them now-would be heroic capitalists done in Soviet realist style. Big men and women in suits and ties, carrying umbrellas and calculators, money spilling from their pockets, making phone calls, doing lines of coke, and shaking hands with smiling customers and clients: heroes of capital and thickset athletes of profit. The second series that Vaclav would produce would be the 'workers' 
series of variously slouching, drunken, dozing labourers and clerks-call centre workers raising middle fingers to their telephones, housemaids sticking employers' toothbrushes up their rectums-also executed in the grand Soviet style: heroic drunks, dozers, saboteurs and time-wasters. He imagined himself describing the hypothetical artworks to the girl downstairs. They would be like Jeff Koons pieces. All plastic, big and modern.

\section{- The PLINTH}

The city was filling up with tourists: the most popular destination in the world. Vaclav looked towards the park on top of the hill, behind the castle. His trained eye could spy the sculpture of a giant red metronome that stood idle above the city. Seven years earlier the red metronome had worked, swinging back and forth, cleaning an imaginary windscreen, but now it stood still. Associations popped into his head: a dashboard fuel gauge stuck on near-empty, or cover art for a heavy metal album. Something heavy about Time.

The metronome sat on top of a huge marble plinth that had once-three decades earlier-suppoited a giant statue featuring none other than the generalissimo Josef Stalin. The statue was long gone and the massive plinth remained. These days skateboarders used the large marble chunks and detritus perfect for grinds and slides. Perfect angles. The red metronome was erected some half-a-dozen years ago at the beginning of the decade. Vaclav had returned to the city—could he refer to the place as his hometown? —at the same time that the sculpture was built.

The metronome, which had worked then and ticked back and forth, from empty to full and back again, was built to commemorate something or other. He wasn't certain exactly. Some people said the thing stood for the general and ubiquitous passing of time, despite all things that have gone and will go et cetera, and others figured on the sculpture symbolising the musicality of the city below, or, who knew with art anyway, perhaps even its unmusicality and propensity to get out of time. Since he was a private person, Vaclav didn't respond well to public art. He liked to think he knew more than just a thing or two about art, and the metaphors seemed so obvious and drab to him. He didn't like metaphors. They were like renaming the combination of stars in the sky into new constellations. Why not ban public art outright? Hadn't Soviet realism taught the population anything? The problem was that under democracy the artwork should, theoretically, be liked or appreciated by more than half the population over the age of eighteen, perhaps even sixteen. Art couldn't number-c runch like that. The metronome was the sort of thing a student made-admittedly on a much smaller scale-in secondary school, when the teacher suggested the big themes as homework, just before the bell rang: death, time, broken fuel gauge. Was it better that the object worked or didn't work? That 
was the question that gazing at the thing raised now in his mind. What about that massive red sculpture on the hill? No, it doesn't really work, does it?

Yet he conceded that the designers and commissioners of the work hadn't been completely wrong. Art was never really wrong, just bad. The metronome reminded him of piano lessons as a child. There was music and there was time. The little machine clicked like clockwork, a little time factory indifferent to melody and nuance, or attempts at such by a child, a young boy; indifferent to the ruler that could crack down hard on the knuckles of his left hand should they falter with the bass notes and rhythm.

Trams rattled, braked and scraped across the four-ways, sounding ding-dings as greetings to colleague drivers, at once indistinguishable from the warnings to drivers and pedestrians. Vaclav stepped outside to the smell of traffic and the smoked meats and sausages in the butcher's shop immediately below. Lacklustre graffiti tags cheapened the grimy grey walls of his apartment block. The crossroads was crowded with cars and commuters. Andean folk tunes played by a group of musicians busking at the entrance to the metro station piped and thrummed across the creaking, cranky traffic noise. The pedestrians stared down at the ground as they walked past one another. The old women had shopping trolleys and the younger ones walked dogs. None of the shopkeepers greeted him.

A gust of wind blew dust up from the street where a group of Romany kids stood outside the McDonald's restaurant, sharing cigarettes. Prague was otherwise a city of white people. He smelled the malt smell of the bre we ry several blocks away, where smoke and steam billowed from the chimneys, and he crossed again to the little tobacco shop at the entrance to the train station for cigarettes and a newspaper. A group of stallholders sold trinkets, books and flowers but most people knew the items were cheaper still at the Vietnamese market a couple of blocks away. The layers of posters that had accumulated on the walls outside the station had peeled back like a ripe scab, revealing the older ones beneath.

The Soviets had built the underground train system in the seventies and eighties. Strictly speaking, Czech workers did the building part though the stations and trains were Soviet designs. These original stations were intended to be, in socialist parlance, like cathedrals for the workers and commuters. Meaningful work was the new faith. Unalienated labour. That kind of thing. Religion, though, is often overlooked as a prime inspiration for socialist aesthetics: the construction of heaven on earth. Religion, which required such repression under socialism, had figured weirdly in the collective unconscious of the institutions that rep ressed it. The veneration of monumental 

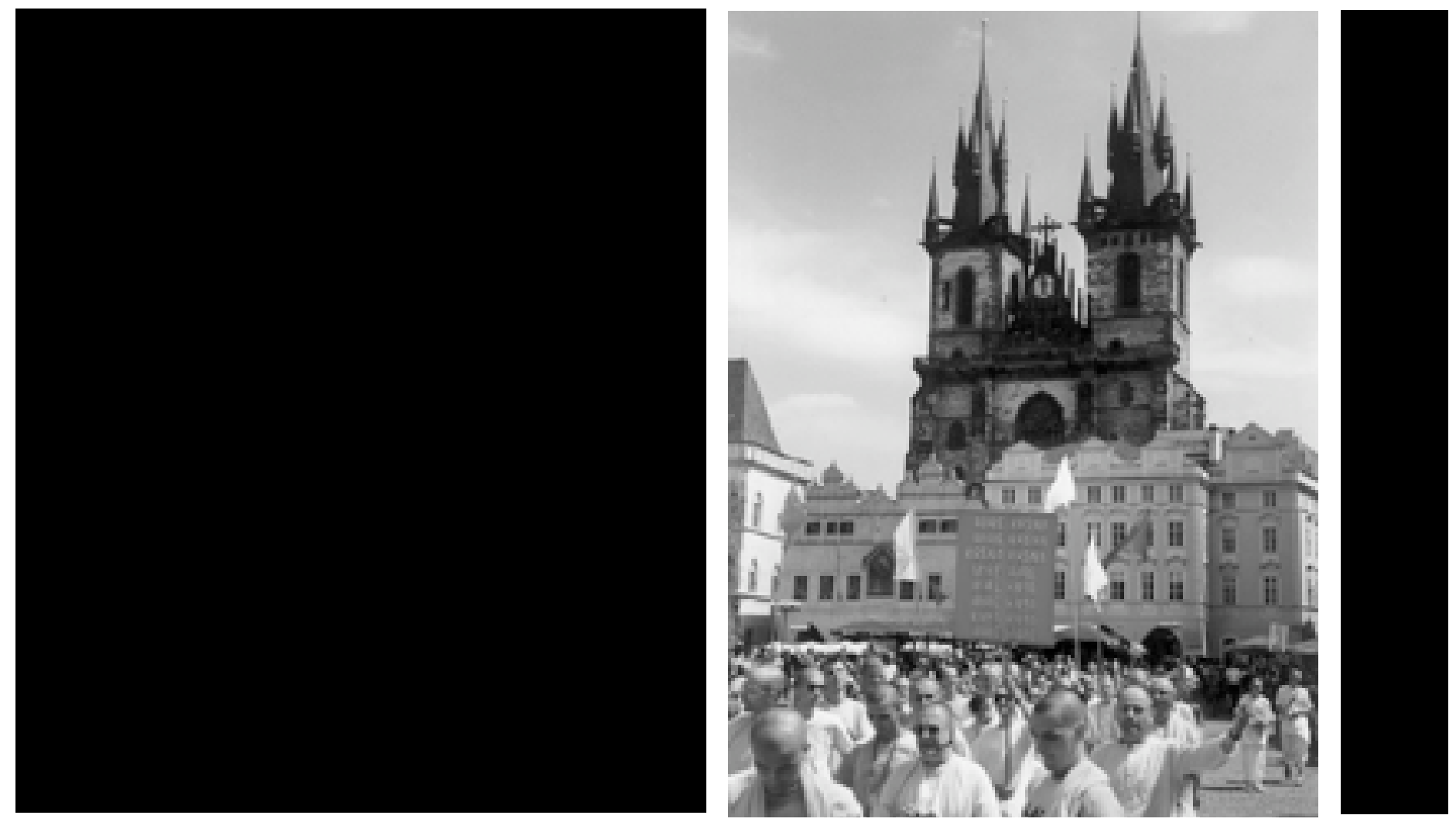

artworks and the role of the pulpit and the confessional broke out in new and other forms

The same trains and metro station designs were typical for the former Soviet capitals. The underground stations included tile mosaics, fabricated steelwork-in bronzes, g reens, oranges and golds-marble work and bronze reliefs depicting the struggles, victories and rewards of Industry, Labour and Science. The mood, nevertheless, was strictly science fiction. Vaclav's station was quite famous and had been called Moskovska until the early nineties.

Late one night in winter he had arrived on the platform and seen a corpulent body covered with a white sheet lying on the tiles. The person had suff e red a heart attack and died in the metro. He and the dead body were the only people there, bathed in a deathly fluo rescent light. The ambience was sinister and silent. He had looked around for cameras and wondered whether a test was underway. Hidden from view around the other side of a column and quietly completing the paperwork were two men, a metro employee and an ambulance worker. Until the men emerged from behind the columns and Vaclav had caught sight of them, he was hoping that what he had walked into was the modernist set of a piece of theatre.

The streets around Wenceslas Square and the Old Town were busy with sightseers, buskers, hawkers, shoppers and police. A tourist group taking a city walk tour in English were being informed that a Hollywood movie had been filmed at a location nearby. Vaclav decided to follow the group for some of the route. The guide had stopped long enough to allow the party to talk about the film together. One man remembered the actual date that 

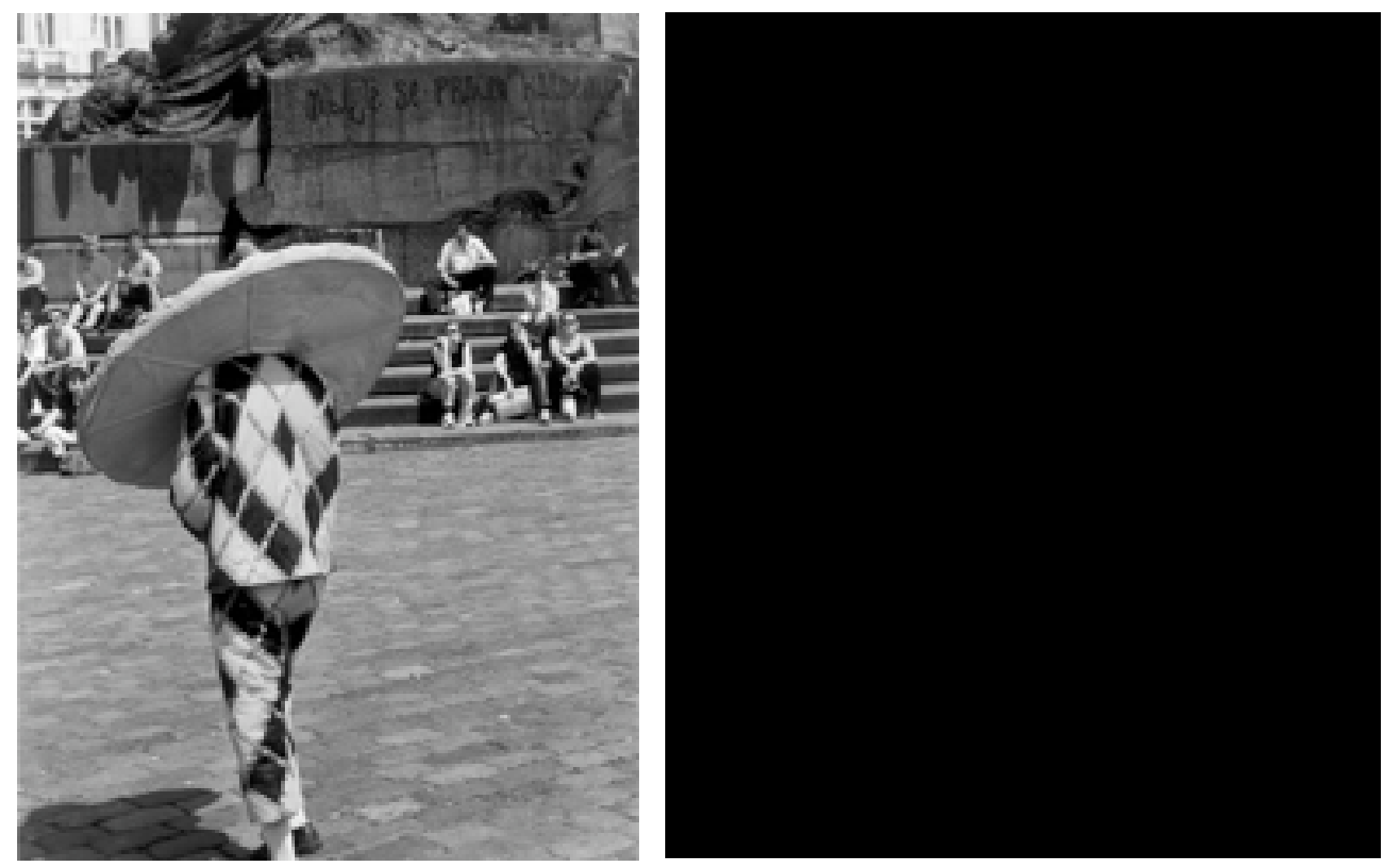

he'd seen the movie and the name of the cinema. The others were impressed. It was difficult enough remembering a plot half the time.

'The Atlantic cinema on Robbs Street, opposite the Chicken Hut. It was summer because I remember thinking that it was too hot, even to eat roast chicken.'

The man's wife and another woman trained their camcorders on the moviegoer. They expected him to say some more. They wanted to hear more of the reminiscence themselves. The group had been away from their lives for over two weeks and they were homesick. They wanted to hear a description of crispy-skinned, greasy roast chicken, cooked the American way. The wife commented that it was unbelievable her husband had vetoed the chance to eat chicken. 'It wouldn't matter if it was fried, grilled or roasted. I've never seen him walk past one.'

Another of the group, a forty-something guy in a baseball cap, commented to the small assembly that that was real history, remembering things like that, the everyday stuff back home and not the fancy monuments and ornaments of foreign countries. Everyone chuckled. After two weeks, tourism felt like duty. They couldn't wait to be home but there were four more countries yet and still seven more days to go.

The crowds around the laneways, crowds that shuffled along the cobblestones and th ronged about monuments, were part of a cheesy procession. Actors dressed as historical personages passed out flyers for piano concertos and pizza restaurants in the Old Town Square. Harlequin types and buxom wenches cavorted and brass bands played. Smithies, tanners, forgers and cobblers went about their obsolete trades in old-style market stalls. 
Modern day buskers and blaggards were liable to leap from behind Renaissance facades o ffering dubious wares to footsore and beauty-saturated sightseers.

Vaclar moved on, trailing the tourist party as they made their way to the old quarter. Ahead he could see two men dressed as Mozarts who had jumped from the laneway and were fighting each other with swords and making loud protestations in German and English. They jostled the group of tourists, bumping clumsily into several camera-heavy types. The duellists appeared to be fighting over ownership of a music manuscript that one gripped heroically and the other repeatedly lunged for. The manuscript looked like the type that held magical spells or cabbalistic formulae. The piece was theatrical, the tour guide told the group, part of the rich tapestry of magical Prague.

The members of the tourist group laughed nervously and clustered closer together like penguins trapped on a scrap of dislocated iceberg and encircled by a pair of killer whales. They allowed the feisty composers to fight among them just as thousands of other sightseers would that summer. Vaclav watched the scenes through his camera lens: an angel's suicide and a pair of frolicking Mozarts. During the shenanigans over the manuscript, he saw one of the great composers sneak two purses and a wallet from the group. When the manuscript was dramatically torn in half and ruined, the group clapped the perf o rmance vigorously, allowing their relief to show in the exaggeration of the applause. Vaclav had photographed the mixed emotions at the denouement and, seconds later, the little smoke bomb that announced the disappearance of the two Mozart characters back into the historical laneways.

Seconds before the smokescreen, through the camera lens, the second Mozart had slipped the tourist guide a five-hundred-crown note. Vaclav lost sight of the actors until one of them appeared beside him and snatched the camera from his hands. The man's face was caked with make-up, his breath smelled of beer and cigarettes, and he wore white gloves. He turned the camera back on Vaclav, snapped a quick portrait of his startled expression, and spoke one sentence in Czech before he vanished into the lanes, taking the camera with him. 'It beats driving taxis. That's for sure.'

A swift green tram arrived at the stop nearby. No sooner had Vaclav twisted into a spare seat than a plain-clothes ticket inspector appeared at his side, requesting to see his ticket.

Two American boys dressed in combat trousers and T-shirts got on the tram at the station and slumped into the seat directly ahead of him, their long key chains resting on the floor of the tram. New tattoos were visible on their fore a rms looking so much like fresh ink on white paper that didn't seem real. The tattoos had probably been done several 
nights earlier in a recordshop near the Old Town Square and they celebrated freedomthe freedom of individuals to roam the world with the knowledge that their futures were secure.

The boys had skateboards and a camcorder and looked like they were skateboarding the big cities of Europe and capturing the whole shebang on camera and streaming it th rough their websites. He bet they were IT types, for no particular reason. Vaclav was jealous of their slack-limbed freedoms. It had been so long since he had been outside his immediate world.

The American twenty-somethings had their guidebook open and were tracing the location of a heavy metal bar near the Republic Square metro station. The guidebook was cooler than more mainstream publications and wasn't afraid to discuss drugs, off-beat music and gay travelling. Such things sold books. Gypsies on trams weren't mentioned. The boys were after pot, and the heavy metal bar was famous for beer and marijuana. The hydroponic Dutch skunk was much stronger and more expensive than the outdoor buds from the eastern region of Moravia. The young Czechs who sold the gear usually gave the Moravian gear away for free to their friends but they could make nice money by selling skunk to the tourists and expatriates who visited the bar. The guidebook advised against purchases made at night outside the bar since such purchases often turned out, in the light of a bathroom or telephone booth, to be leaves from any old shru b.

Some evenings the place resembled a bar from Star Wars on account of the incongruity of people gathered there beneath the sonic assault of punk music and heavy metal. The success of the trade indoors had attracted dealers outdoors and the metro station exits had at least one person at each selling drugs. There was the usual crowd of skaters, ravers, punks, Goths and skinheads inside the bar but, sitting awkwardly at this or that table or bench, there were American accountants, for instance, on lunchbreak or backpackers, attempting a more inconspicuous unease beside the workers. People disappeared out the back for a while.

The two boys were due to leave for Budapest the next day. Vaclav couldn't help but hear the American English. He needn't even eavesdrop. A section of his brain lit up at the English words. He had heard that pot was easier to buy in Prague and simple enough to carry across the border when wrapped in foil and stashed down the underpants. They were practising the Czech phrase for 'Hello, do you have grass?' with one another. Not that it was necessary to ask for the stuff in Czech. Like beer orders, it was just a bit cooler.

The boys knew the two questions—and nothing else besides—in nine different languages. Their collective goal was twenty languages. They could score marijuana and order beer in countries scattered all across Europe and Asia. They had been taught 'Dobry den. Nemate travu?' in the youth hostel the previous night, and they repeated it now to 

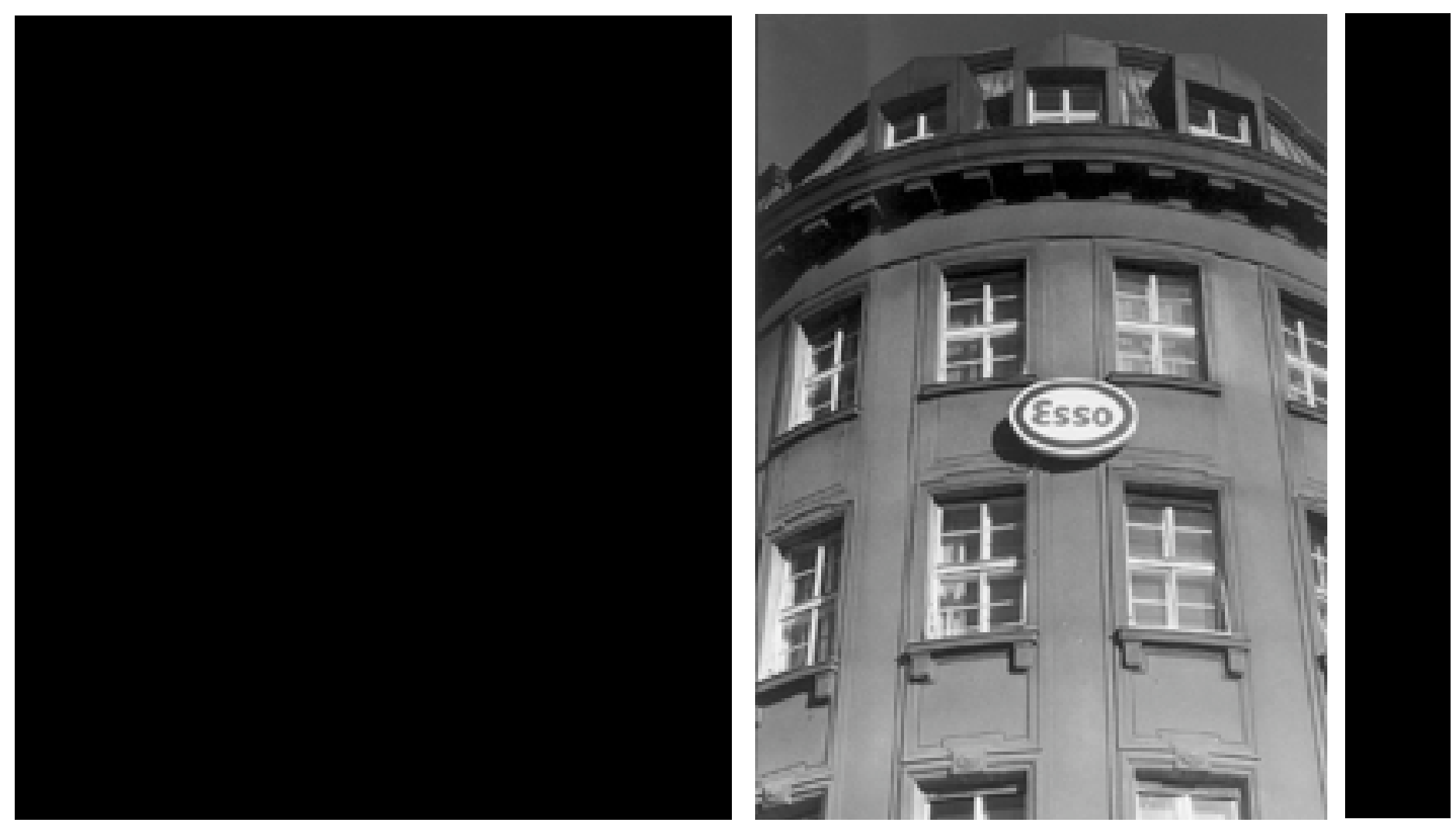

one another, over and over, for effect and so that it might roll from their tongues. 'Do you have any grass? Do you have any grass?'

The other people on the tram were on the brink of laughter or outrage but the boys we re quite oblivious to the effect that their rehearsing was having on a tram full of Czech people. Their obliviousness operated as a foil for the boys. They were the only two who understood the phrase, it was a secret formula they had been taught, and they acted like they were still home in the United States, where people on trams spoke English and wouldn't understand Czech expressions. The obliviousness was a fundamental disconnection that provided insulation for their travels.

It caused Vaclav to wonder whether a certain desensitisation was required in order to travel blithely around the world. As usual, when he thought about such things, he felt like an egghead merchant of doom. He could imagine the boys' response. 'Yeah, whatever. I'm full of guilt. Like, racked with the shit.'

The new anti-globalisation protests confused him, although he had been in the one in Prague. More specifically, the hype that surrounded them provided the confusion. Which protests were directed against globalisation and which were promoting nationalism? Anarchists wouldn't riot in favour of nationalism-which was simply a smaller version of globalisation—and nationalists would hardly want cheap, global labour entering their countries and taking their jobs.

The various protest camps could be lumped together, by journalists for example, and ridiculed as amorphous and unclear. Some smashed up McDonald's because the farming requirements of the international hamburger industry were deeply unecological whereas 
others destroyed the restaurants because they failed to use the local economy's own dairy industryproducts.

The protests were odd and unpredictable. Newspapers were usually quick to point out apparent hypocrisies among the protesters-brand-wear, fast food, leather jackets, religious people, violence-but the amorphousness of the mob lent itself to inconsistencies.

He often interrogated the cliché that travel broadened the mind. What was travel now? He wondered how exactly it happened, and whether the thing that broadened the mind wasn't in fact the stint away from home, and not especially the appreciation of various other ways of living. The boys, for example, seemed sufficiently able to block out much of the everyday reality of the city and populations they were travelling through. Had the English princes and nobles on their Grand Tours of Europe been different a century earlier? Vaclav thought of a Formula One computer game in which the background landscapes changed but the fundamental objective remained the same irrespectively: drive fast and stay on track. The completion of the task was in fact complicated by the changing backgrounds, so these were best blocked out.

The two boys attracted and disgusted Vaclav. There was the ubiquity of their look and the global brand names that made him think along the lines of 'Sure, you ride skateboards. Cool, but why do have to look like you skate?' Then again, why did librarians and teachers look like librarians and teachers? Subcultures had made sensethat is to say, were simpler to identify-before they were so effectively co-opted by multinationals and thrown back at rebellious youth as consumer choices. They had to get smarter in response to global marketing; that is, if they cared to retain or even considered the notion of subculture.

The boys looked like sloppy demographics. Pop culture was a trip. Vaclav thought he could track the paths of the skaters' futures through various advertising campaigns in a lifestyle magazine. When they grew old and played golf together, they would reflect on a life of transactions. Right now, though, the boys looked great, the way American boys could, like wasted angels.

The two boys didn't have tickets but managed to ignore the ticket inspector the first few times he addressed them in Czech, continuing to rehearse their mantra, 'Do you have any grass? Do you have any grass?'

'Dobry den. Mate jizdenku?'

'Nemate travu? Nemate travu?'

One of the boys pulled a guidebook from his backpack and opened towards the back page. 'Where's that word, dude? We need that word.' 
The other boy asked the inspector to speak English. 'Only English here, man. Americanos.'

Vaclav considered their form of travelling peculiar; though, of course, he was assuming so much. The boys were clued up enough to score drugs around the entrance to a metro station but couldn't understand the mundane and everyday commerce around them.

The American boy with the guidebook looked up and said two words to the ticket inspector. The ticket inspector shook his head. He didn't care that the two idiots couldn't understand, and in fact he had expected that. He wrote ' $400 \mathrm{k}$ ' on a piece of paper, referring to the fine in Czech crowns. The boy continued repeating the phrase for 'we don't understand' in order to indicate to the ticket inspector that it was his turn now to b reak into English and they would sort out the situation. The other boy was attempting to figure out the significance of the number written on the paper.

'What is this? Four hundred k. The guy wants four hundred thousand. Four hundred thousand what?'

'I'm saying the fucking words right but the asshole doesn't understand his own language. Hey mister, we have to listen to foreigners fucking up our language every day. At least we're trying.'

'Four hundred thousand dollars? Fuck you, man.'

A group of Czech schoolgirls congregating around a pole next to the American boys laughed at the obscenities. The tram rattled past the currency changers huddled across from the main post office and approached the metro station stop. The boys were calling the ticket inspector 'fat Nazi' when one of the schoolgirls—no doubt dared by her friends because she had the best English-explained that the four-hundred-crown fine was because they didn't have tickets. They thanked the schoolgirl and invited her and her four friends for beer with them but the girls pointed to their English language textbooks and shrugged their shoulders.

'Hey, with us. You ladies will get the language lesson and the cultural lesson too. Free of charge. It's only four hundred crowns, man. Chicken feed. Hand the Nazi his money and let's go find that bar.'

The boys stood up and looked back at the girls. One of them asked whether they were certain they didn't want to join them for beer and grass. He made a smoking gesture with his fingers and sucked through his teeth. The tram arrived at the station as the boys paid the fine. They swung out of the door, saluted the inspector with their middle fingers, and didn't bother waiting to collect their receipts for the payment of the fines.

Vaclav followed the American boys past the bookstalls and down the escalators into the station when he remembered the gift he had to buy, a bottle of absinthe and some 
Moravian plum brandy. He walked to the little supermarket on Wenceslas Square to buy the alcohol, probably the most expensive place in the city, and returned to the metro station. The two American boys were on the escalators in Mustek station. This time they were travelling up the escalator in the company of two metro police officers. Vaclav was travelling down to ride Metro Line B.

Ticket inspectors were at the bottom of the escalators, picking commuters off like flowers in the springtime. The impression Prague sometimes gave during the high tourist season was of a minor police state but, ironically, the police were in force only because the tourists were in force, evading fares and getting ripped off .

The two American boys had been caught again travelling without tickets. Vaclav did feel sorry for them. They hadn't taken the receipts from their earlier fines to show as proof of ticket purchase. They hadn't the cash to pay the next fine and couldn't explain their previous dealings to the police. Vaclav could have helped, but he didn't. The conveyance was taking him elsewhere. Nothing bad would happen to them and he had other things to do. They would be taken to the police station and later walked to the American Express o ffice. Money would exchange hands and they wouldn't go without their pot. He and the boys were travelling in different directions.

\section{- Metronomics}

Later that afternoon, Vaclav parked himself on a bench in sunshine, lit a cigarette, and leafed through the newspaper while his dog Blanka ran around Letna Park, chasing soccer players and skateboard riders. Occasionally, she stopped scrambling after the youngsters for a moment and looked across and down from the hilltop park at the spires, lanes and tiles of old Prague across the river. Man and dog had walked from Vinohrady through the town centre in order to visit an adult bookshop, the post office, a couple of small art galleries run by acquaintances of Vaclav's and an antique bookshop, whose owner had recently died and been replaced by his barely twenty-year-old grandson, a square-eyed net surfer. Vaclav had explained to Blanka as they crossed Karlovy Namesti that they had a busy day ahead of them. Blanka was muzzled and attached to a lead as the law required, hating the uncomfortable muzzle but relishing the day out of the apartment.

Vaclav took lunch in the Komotra pizzeria in one of the lanes off Narodni Trida, pretending to study a new book of photographs while spending much of the time attempting to catch the eyes of the various students from the university faculties nearby. He prefe red to eat upstairs in the cafeteria section and be waited upon by the pretty blonde girl. He was good-looking but drably unfashionable. The moustache was something he couldn't remove because it seemed as permanent and defining a feature of his physiognomy as his nose. 

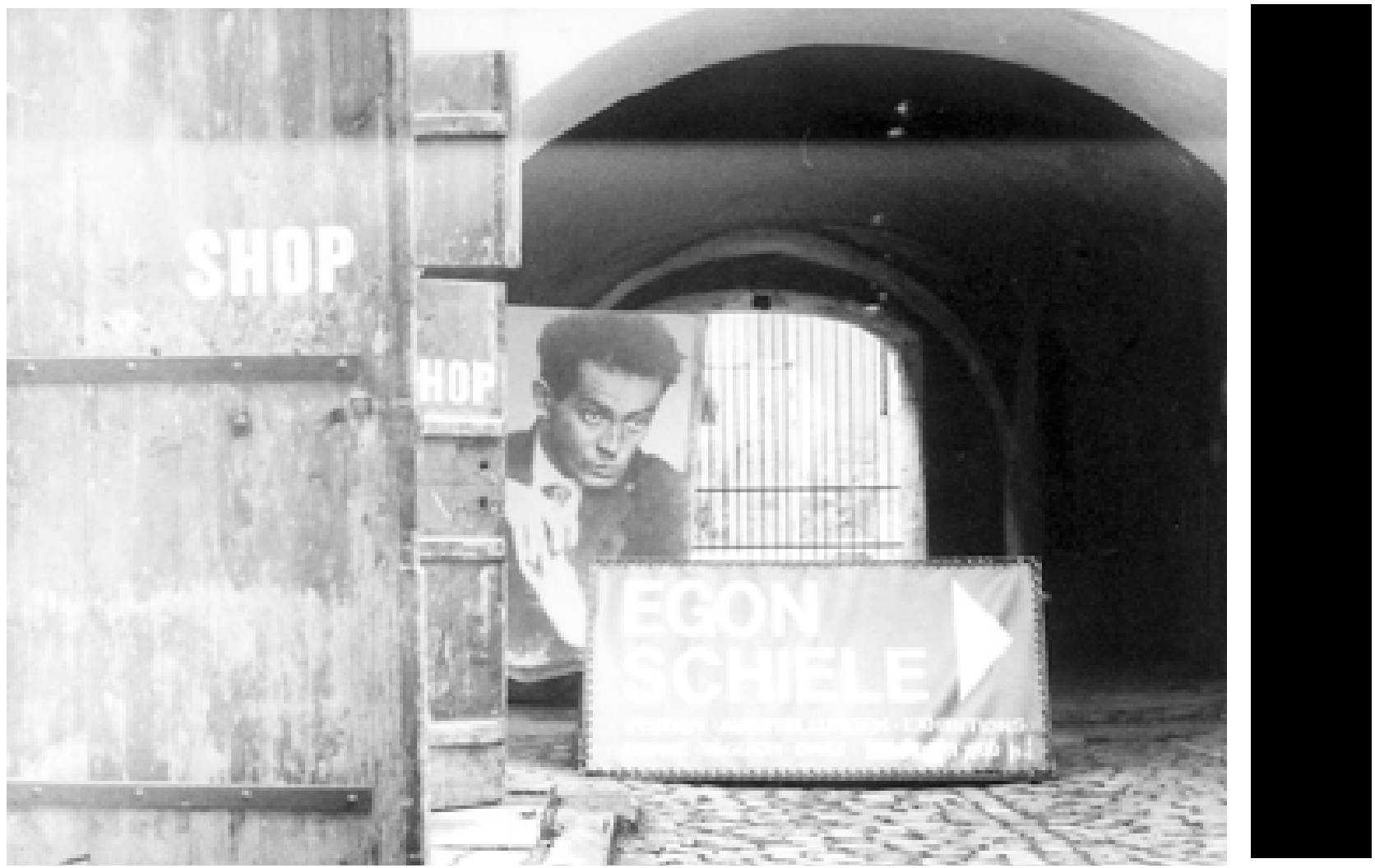

Downstairs was usually busy with customers and efficiently worked by a team of fit and tattooed male waiters and kitchen staff. Vaclav felt guilty and downright lazy dawdling at the table to read and ogle during and after the pizza meal as the young men zipped a round him to beat-driven music. Not guilty, just old. Redundant. What value were his dusty thoughts and outmoded knowledge? What could he ever possibly achieve and present to people that could touch the service of pizza these men provided? The best pizza in Prague. Upstairs, where he pre fe red to sit, he could let the slices go cold on the plate as he liked—and he did and he would—and watch Blanka outside, attached to a parking meter.

The pizza filled both Vaclav and the dog so they caught the winding tram, rather than walking, from outside the New Stage of the National Theatre, beneath the cladding of sound-insulation blocks, made of specially blown glass-more than four thousand of them, each looking like the insides of a TV-past the closed-down former dissident coffee shop Slavia, whose current fate was being debated, across the river Vltava and Kampa Park, and onto the lively Ujezd intersection. Vaclav enjoyed stumbling into the rock venue near the corner, now and again, after a gallery opening in the centre.

The tram continued through tourist-thronged and pint-sized Malastrana-the Little Quarter, where it was easy enough to imagine a crooked Kafka scurrying from gove rnment office to garret, the thuggish drones of The Trial replaced by the faceless tourist hordes - and up the hill, towards the castle, and eventually to the park immediately overlooking Prague. Vaclav liked the illusion that he fled up to Letna in order to think when, most likely, he was there to quietly panic. 
The 1:1 scale model of Prague lay below the park as if meticulously constructed from cardboard, clay and paint. All of Prague-from the panelak housing estates that ringed the city limits to the orange-and-red tile roofs that marked the centre-might be seen from the plinth on the hill, where the dormant red metronome waited and the skaters did tricks.

Two years before-it seemed shorter than that but then everything did-American pop star Michael Jackson had launched his world tour with a massive concert in Prague. More than one hundred thousand people crammed into the Strahov Stadium for the show. A ten-metrehigh, blue-and-white anodised steel statue of the superstar had been erected on the Letna plinth. From this location the figure might be seen by most people in what amounted to the basin of central Prague: the Old Town, the Jewish Quarter and Republic Square. Some older people must have shaken their heads and muttered to themselves. 'First Josef Stalin and now Michael Jackson. What's next? Mickey Mouse?'

The metronome still didn't work. Vaclav didn't know whether the sculpture was deliberately idle or broken down in order to stand as a metaphor of sorts. Maybe the engine was kaput and it hadn't been repaired. Were letters written to newspapers and politicians demanding explanations? The replies could be written by critics who preferred interpretations of the metronome piece to clinical explanations.

The government most likely hadn't sufficient money to spend on maintaining a giant red metronome sculpture. Art couldn't be trusted to take care of itself. Tourists thronged th rough central Prague six months of the year, wearing away architectural details with their traffic, and city residents drove cars and rode trams beneath Letna Hill, and yet still the sculpture didn't budge one measly inch. The monument to time had stood still, or was being allowed to stand still, through neglect.

The red metronome sometimes reminded Vaclav of the closed mechanical arm that greeted motorists at the entrance to a car park. Vaclav didn't like car parks or ludicrous public sculptures. Public art spectacles and giant objects seemed sopre-1989.

Furthermore, Vaclav believed that the site was haunted. Delicious chills and curlicues of electricity coursed through his body at the thought of the haunted grounds surrounding him.

The psychological landscape of the city was delineated by four points that might, for example, be imagined as the four corners of a boxing ring or, at a stretch, the four legs of an upturned table. The castle and the gargoyle-adomed cathedral loomed over the city basin in the west, above the river and the hamlet of the Little Quarter. That's Kafka scu rrying about down there, appalled by the gaudy souvenirs and English expletives, unable to find his way home through the labyrinth of tack.

The ancient castle of Vysehrad, the original site for the city, stood a couple of kilometres along the river to the south. The river flowed north and south through the centre, crossed 
with a number of fjords to ensure the continuous flow of water against the prospect of the river freezing, and pocketed with intricate lock systems for the commerce of shipping.

Spin around to face the east and the Hussite general Zizka sits on his horse-the largest equestrian statue in Europe-having vanquished the Papist armies in the battle of 1420 on Zizka Hill above the inner-eastern quarter of Prague known colloquially, on bumper stickers, as the People's Republic of Zizkov. Finally, the hill of Letna Park constitutes the northern aspect of the old city where the statue of Stalin stood for seven years. Vaclav sat beside the large plinth and beneath the metronome, watching Blanka chase footballs. Bound within the circuitry of these four points-the psychic energy flowing invisibly along the ropes of an imaginary boxing ring-are the old and central quarters of Prague. Vaclav imagined that when people wrote of magical Prague, they described the forces that operated within the fields of the four points.

Vaclav went to the Michael Jackson concert with Helena and a bunch of friends, despite not being a great fan of the pop star. The spectacle was worth the crush and cacophony. The tickets had been free. He thought of himself as curiously bonded with the plinth and, indeed, the neighbouring woods on account of the events that had occurred there during his lifetime.

\section{— The Queue FOr MEAT}

The statue of Stalin on Letna was built in 1955 and publicly unveiled on the very same day that Vaclav was born in Moravia. He had only seen the actual monument twice but, nevertheless, the image of it was stored in his memory-from those two childhood visits-as being a monument not unlike the Sphinx. Perhaps the analogy of the Sphinx had come much later to Vaclav—after those first seven years of his life—from subsequent history lessons and television programs. The spectre and riddle of the ancient Sphinx had assumed the place of the statue in Vaclav's young mind. That was what he meant.

The monument to a despot and his team of model citizens was dynamited to smithereens in 1962, about the same time that Vaclav set off fireworks in insects' houses in the countryside. There were to be no further trips to Prague for the family. Photographs of the Stalin monument were extremely difficult to find once the monstrosity had been explosively removed from the public psyche and the Letna Hill.

Returning to the 'upturned table' idea-Vaclav's magical circuitry-the northern table leg where Letna Hill stood was the weakest link. He imagined the invisible energy gushing th rough the broken link, like a boxer crashing through the ropes, like water streaming th rough a crack, and he shifted uneasily on the park bench beneath him.

The statue had not simply been of Stalin but had been a monument to his Soviet visions. The enormous figure towered at the front and centre of a tableau and reached a 
height of fifteen metres. Behind Stalin—on his right-hand side and in a line-were four smaller figures re p resenting Czechoslovak citizenry: a worker carrying a large flag, a woman farmer, a scientific inventor, and a soldier at the rear of the line whose head was turned to look behind the group. The soldier may have been guarding the flank or, it was difficult not to think these days, simply had his head turned around in order to look the other way.

Four equivalent stereotypes of Soviet citizenry had then stood in a line behind Stalin's left soldier. A worker was draped in a flag in front of another female agricultural labourer from a collective farm. An agricultural scientist stood between the farm labourer and the rearguard Red Army soldier. There didn't seem to be any avant-garde painters, composers or writers depicted in the group: perhaps they had snuck off for a quick drink. The monument had been twenty-two metres long and the plinth alone was fifteen metres high.

The statue of Stalin, the Slavic liberator of Prague after the German occupation during the Second World War, would have been visible from the Old Town Square in the centre of historical Prague, and visible to the strollers along the elegant Paris Boulevard. A person might stand in front of the Old Town Hall, for example-one neo-Gothic wing of which had been burnt down by the German soldiers in 1945-and look up at Stalin (and later the red metronome and, later still, Michael Jackson) from the town square, the same town square where Hapsburg rulers had executed over twenty Czech nobles in 1621. The Letna position was therefore a dramatic and poignant one.

A design competition was conducted in 1949-before Vaclav's parents had even maried-and work was begun on the monument on Stalin's seventieth birthday. Two thousand kilograms of dynamite had been required to demolish the statue that early morning of 1962 . History records the order given to the demolition team by the municipal authorities as insisting that the thing go quickly, without much of a bang, and be seen by as few people as possible. Stalin et al were concealed one day inside wooden scaffolding-like swimmers wrapped in a towel and attempting to hide the all too obvious fact that they were removing their trunks-and then blown up. That was how history was rewritten, like a misspelt or inappropriate word scratched and scribbled out of the page of a notebook.

The Stalin monument - the locals affectionately referred to it as 'the queue for meat' was officially opened in 1955; the day that little Vaclav kicked and screamed his way into the modern world. The Soviet authorities were angered to learn that the designer of the monument, a Czech sculptor, hadn't attended the opening ceremony as a result of having earlier committed suicide. Finally, eight years later, a West German business had offered to 
purchase the considerable amount of scrap metal left behind after the demolition. The Czech government - undoubtedly under the influence of Soviet authorities—refused the generous off er, which further angered and disappointed the Czech people.

The generalissimo was to be buried on Soviet soil. Photographs of the statue have been ext remely difficult to find since 1962, although Vaclav had managed to buy a print taken by the Magnum photographer Erich Lessing. The plinth, nevertheless, remained, and covered an underground space of almost two thousand square metres. For many years, the communist government stored potatoes there.

Vaclav felt a fond affinity with the Letna site because, since the demolition in the early sixties, the dark and winding paths around the plinth and through the woods had been a night-time cruising area of sorts for homosexual men and-two birds with one stone-a place to smoke marijuana and enjoy the panorama of historic Prague. After completing school studies and then university in Germany, Vaclav visited Prague regularly to stay with his grandparents and visit his cousins under the official pretext of research. Most nights during those several years, he had snacked on the nocturnal fruits of the beat in the Letna woods, continuing a practice-towards which he had at first been ambivalent-that had blossomed at boarding school.

The fragrant summer nights remained in Vaclav's mind whenever he thought about Letna Park. Marriage had visited heterosexuality upon him for the last ten years. The memories were like clusters of aromatic and flowering weeds growing among the trees and paths of the Letna woods. Homosexuality was something that Vaclav consideredlike skiing and sketching —as a hobby.

He looked up from the newspaper in an attempt to locate the dog somewhere in the park. The skateboarders and bike riders were performing tricks on the steps and stair rails a round the plinth. Families walked around the shrubbery and paths that had once provided Vaclav and others with protection for their proclivities. The sun shone down on a reas he prefe red to recognise in darkness.

Vaclav considered a group of children playing hopscotch on the footpath beneath the window of the apartment. He remembered his own childhood spent largely in boarding schools. He blinked and held his eyes closed for a moment. He considered a thirty-metre high statue of children playing hopscotch. He thought about the communist state's attempts to replace religious belief by using classically sacred forms, like monuments and statues. The obsession with erasing and undermining the narcolepsy of religious thought and belief had allowed communism to re p roduce the methods of its religious anatgonists: prescriptive and proscriptive art practices, the pulpit-driven public addresses and the monumentalism. 
Of course, the replacement hoped to show that people could be gods on earth themselves and to eliminate distinctions between humanity and divinity. Heaven was on earth. That sort of thing. The great leaders immortalised in stone and the noble workers and dutiful scientists were all as gods on the earth. Vaclav suddenly remembered anarticle he had read recently about a new theme park in Lithuania or Estonia, certainly a former Soviet bloc country, where many of the public artworks from the Soviet era had been collected and were on exhibition. The place was a triumph of kitsch: a Disneyland of dictators. It made him sorry to think that Stalin's monument wouldn't be among the parade of Donald and Daisy Ducks.

A block of ice slipped from Vaclav's mouth and dropped to the footpath below. The children looked up at the apartments and Vaclav waved down at them and raised his glass. He felt as if he were waving at himself as a child. 'Na zdravi, children.'

He toasted the child on the streets of Prague that he had never been, the whole time tucked away in a dorm it o ry in Geneva. The little block of ice slowly melted on the cobblestones and the water smudged the outline of a small part of the chalk-drawn hopscotch course.

One particular year an enormous block of ice melting in a public square might have represented, for example, the demise of communism and the Warsaw Pact throughout eastern Europe and the thawing then of world relations, the blurring of lines and boundaries. Vaclav thought about the admonishments delivered by various communist leaders in earlier years concerning the West's plans to take control of the world and dominate the economies and politics of various regions. The dire warnings had seemed like paranoid rants. After the fall of the Berlin Wall, the popular rise of Solidarity and the Velvet Revolution, millions of eastern Europeans could access the markets and freedoms available hitherto only to citizens of liberal democracies.

The euphoria had lasted some several years and certain post-communist leaders, like Vaclav Havel, had assured the West that just as the infant democracies-cute as baby dinosaurs - had much to learn about the processes of liberal democracy and a deregulated marketplace, so too these baby democracies could contribute much to a dialogue of mutual enlightenment by providing examples-derived from the decades of communist rule and lessons of abuses and oversights-to Westem nations.

The warnings of the Soviet-era leaders no longer seemed like paranoid ranting but, in fact, prescient observations. Vaclav looked again at the ever-diminishing block of ice and decided that the hypothetical and public ice installation could, in another particular year, another era, represent global warming, the melting of the polar ice caps, and worldwide environmental meltdown. He wished he could express these sentiments and concerns to others and share with them the confounding duplicity of modern art and existence. 
Later he will go for one of his walks and find that a giant billboard with a smiling face and accompanying text has been erected on the plinth and is looking down on historical Prague. At first Vaclav thinks the thing must be a cigarette advertisement, the latest Marlboro campaign. The city cowboy. The look, however, is all wrong for cigarettes; more corporate than cowboy. Perhaps the cigarette company has simply brought the cowboy image up to date. It is a long time, after all, since he has been to the cinema. Then he recognises the face on the billboard. It's a politician, running for office, a fellow who is going to rule the country one day, according to some of the journalists. That one up there who is beaming like a proud father, hopelessly unaware of the pains of labour ... Of course, he thinks! First there was the dictator, and then the pop star, and now the beaming senator. They are one part public servant and one part pop star. There is the difference. Stalin's monument, at least, was built several years after his death. Bearing that in mind, it might be seen as a mausoleum or headstone. These modern politicians, though - they start work on huge monuments to themselves before even they assume the o ffices of power. Before anybody votes for them. They create their personality cults early. The headstones come first.

JULIAN HARRIS teaches ESL at the University of Queensland and plays drums with The Golden Circles. 